\title{
伝統的建築物の照明における最適色温度の決定に関する研究
}

\author{
非会 員 張 明 (富山大学) 専門会員 中嶋 芳雄 (富山大学) 専門会員 高松 衛（富山大学） \\ 専門会員 千代 和夫 (パナソニック電工 (株) ) 非会 員 馬 林 (富山大学)
}

\section{Research on Color Temperature for Illumination of Traditional Buildings}

\author{
Non-member Ming Zhang (University of Toyama), \\ Fellow Member Yoshio Nakashima (University of Toyama), \\ Fellow Member Mamoru Takamatsu (University of Toyama), \\ Fellow Member Kazuo Sendai (Panasonic Electric Works Co ,Ltd) and \\ Non-member Lin Ma (University of Toyama)
}

KEYWORDS : traditional buildings, colored temperature, image evaluation, factor analysis, light-up

\section{1.はじめに}

日本の伝統的建築物は, 歴史一文化一民族を表し，それらを理 解するために欠かせないものであり，民族の精魂を込めた重要な 文化財でもある，近年，多くの伝統的建築物はライトアップの手 法によって, 新たな魅力の創出や幻想的な演出が盛んに行われて いる。一般的な都市構造物と異なり，伝統的建築物はその時代を 反映する特別な意味を持つものである. ライトアップするに当た っては, 如何にして, そのものの特徵を演出し, 且つ美しさ, 親 しみや寸さ, 芸術的な, 環境のやさしさ等の要素を融合した景観 照明設計が期待されている.

そこで, 本研究では, 上述した観点から, 照明光源の色温度がラ イトアップされた伝統的建築物に及ぼす影響について, 定量的, 数 量的に評価し,さらには, 因子分析法により, 得られた結果を基に, 伝統的建築物の夜間景観照明光源の最適な色温度を決定すること を目的とした。

\section{2. 実験}

\section{1 景観サンプルの選定・作成}

本実験では，主に石造白色外壁の『城郭』，木造赤色や木造焦げ 茶色外壁の『神社』, 『寺』, 『歴史的町並み』の四種類の『伝統的建 築物』を対象をとし, 京都, 北陸エリア内の計 22 ヶ所の伝統的建 築物を実験用のサンプル地点として, 選定した (図 1 参照)。それ ぞれ,「城郭」は 3 箇所,「神社」は 5 箇所,「寺」は 9 箇所, 「歴史 的町並み」は 5 箇所である. 四種類の『伝統的建築物』を等価に評 価する理由としては, 均一の撮影距離と同じアングルを保つ場合, 撮影器械の視認性により, 異なる印象の生じを避ける根拠が得られ たからである。

選定した地点の夜景（既存の照明状態）をデジタルカメラで，撮 影寸る，なお，実験に合わせるため， (1)人間と撮影器械の視認性に

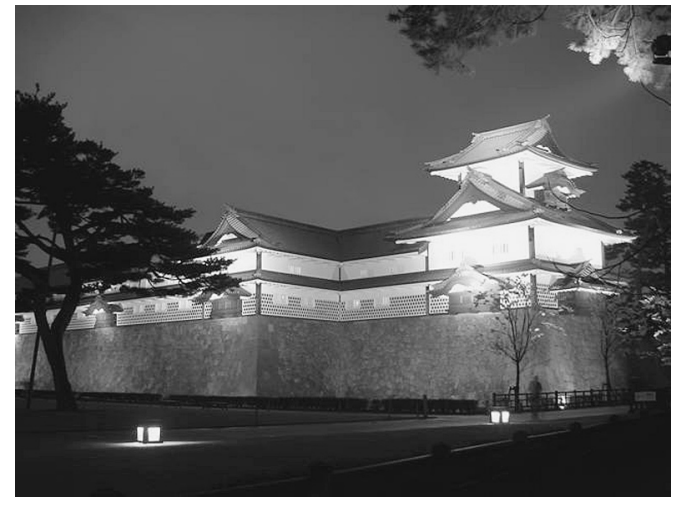

図 1 実験サンプル写真例 金沢城（金沢市） Fig.1 Sample photo used in this experiment.

影響を及ばず良い天候であること；(2)撮影地点から対象物まで, (3) $60 \mathrm{~m}$ 前後（多段階距離で撮った写真の印象測定を行った結果） の距離を保つこと; (4)デジタルカメラスタンドを地面から $1.2 \mathrm{~m}$ の高さを維持すること；(5)撮影角度を $23^{\circ}$ 前後（誤差が小さく， 精度が最もよかった）に維持することなどというような統一条件 に揃えて，写真の撮影を行った。

サンプルの試作をする前に, スクリーン上の撮影した写真の輝 度值を測った。 その目的は最大平均輝度值と最小平均輝度值の中 間平均值をとり, 画像処理を行う際に, ダーゲットの平均輝度值 を決めることである．また，ダーゲットに影響を及ぼさないため に, 周辺の輝度值を $0.5 \mathrm{~cd} / \mathrm{m}^{2}$ 以下に抑えた. 上述した基準に従い, 撮影した写真をすべて画像処理ソフトにより，照明光源の色温度 を変化させ，156 枚の実験用サンプルを作成した。

実験に使用した照明光源の色温度は，自然光との対応関係に基 
づき, 色温度変化の軌道から, 選んだ代表的な 4 段階モデルである. 具体は以下に示す.

( i ) $(\mathrm{x}, \mathrm{y})=(0.527,0.413)$ の $2000 \mathrm{~K}$ の光色;

(ii ) $(\mathrm{x}, \mathrm{y})=(0.437,0.404)$ の $3000 \mathrm{~K}$ の光色 ;

(iii) $(\mathrm{x}, \mathrm{y})=(0.333,0.333)$ の $5500 \mathrm{~K}$ の光色 ;

(IV) $(\mathrm{x}, \mathrm{y})=(0.281,0.2888)$ の $10000 \mathrm{~K}$ の光色 ;

\section{2 評価・分析の方法}

各サンプルに対する評価を行うに当たっては，代表的な方法の一 つである SD 法 1）2）を用いた。 実験に使用する印象評価語を決定す るにあたり， 23 人を対象に, 伝統的建築物に対する印象を自由に記 述させる方式を採った．先行研究と国語辞書に基づき，記述させた 287 個の印象語の中から伝統的建築物の印象に適切であると思われ る 21 個を選出し, その反対語を選定して表 1 に示す 21 対の形容詞 を作成した，評価は 7 段階尺度で，「どちらでもない」（0 点）を中 心にして，それぞれの形容詞に向かって「やや（1もしくは-1)」， 「かなり $(2$ もしくは-2)」,「非常に（3もしくは-3)」とした.

\section{表 1 評価形容詞対}

Table1 Adjectives used in for evaluation.

\begin{tabular}{|c|c|c|c|}
\hline 1) & 開放的な一閉鎖的な & 12) & 派手な一地味な \\
\hline 2) & 快いー不快な & 13) & $\begin{array}{c}\text { 親みやいーとっつ } \\
\text { きにくい }\end{array}$ \\
\hline 3) & すっきりしたーごてごてした & 14) & 好き一嫌い \\
\hline 4) & 暖かいー冷たい & 15) & 古風な一現代的な \\
\hline 5) & にぎやかなー寂しい & 16) & 明るい一暗い \\
\hline 6) & 陽気な一陰気な & 17) & $\begin{array}{c}\text { 芸術的な一非芸術 } \\
\text { 的な }\end{array}$ \\
\hline 7) & 安息感－緊張感 & 18) & 立派な一貧相な \\
\hline 8) & やわらかいー硬い & 19) & $\begin{array}{c}\text { 厳かである一厳か } \\
\text { でない }\end{array}$ \\
\hline 9) & 美しい一醜い & 20) & $\begin{array}{c}\text { 落ち着いた一落ち } \\
\text { 着かない }\end{array}$ \\
\hline 10) & 調和した一不調和な & 21) & 動的な一静かな \\
\hline 11) & 目立つ一目立たない & & \\
\hline
\end{tabular}

実験を行う際は, 暗室の条件下において, 被験者の前方に写真步 ンプルを映すスクリーン $(\mathrm{W} 1.8 \mathrm{~m} \times \mathrm{H} 1.8 \mathrm{~m})$ を配置し，液晶プロ ジェクタによってほぼスクリーン全面の画面サイズで実験用写真 サンプルを映し出し，被験者に観測してもらう方法とした．被験者 とスクリーンの距離は $4 \mathrm{~m}$ である. 各景観について得られたデータ の平均值をその景観の評価値とした. 被験者は 30 名の大学生で,

男子 22 名，女子 8 名であった。 なお，被験者の心理，すなわち気 分や状況などに配慮し，誤差を少しでも減らすように環境を整え て, 慎重に実験を重ねた。

SD 評価データの解析には, 因子分析法を用いた。この解析によ り, 類似する印象語から対象への総合的な印象を把握することがで きるからである ${ }^{3}$.

\section{3. 実験結果及び考察}

$\mathrm{SD}$ 法による全サンプルの評価平均値を図 2 ([a] 〜 [d] ) に示 す. 円周方向には形容詞を, 半径方向には評価值を, 黒太線で表示 された不規則円形には四段階の色温度をとった．2000Kと $3000 \mathrm{~K}$

([a]，[b]）の結果より; 動的な，開放的，暖かい，にぎやかな, 安息感, 目立つ, 親しみやすい等といった形容詞の評価值が大きく, $5500 \mathrm{~K}$ ([c] ) の結果より; 立派な, 芸術的な, 古風な, 好き, 調 [a]

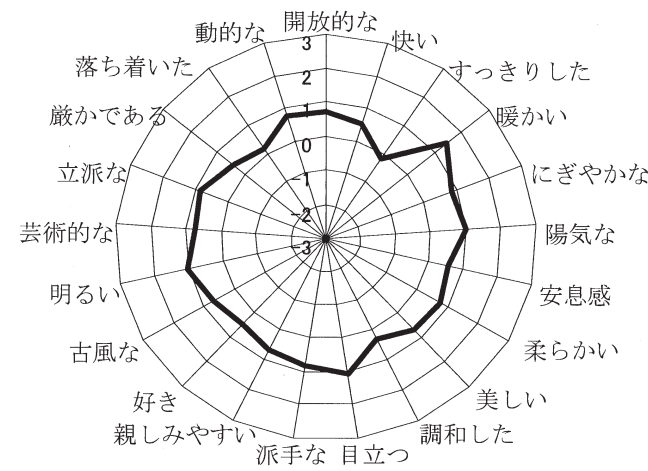

[b]

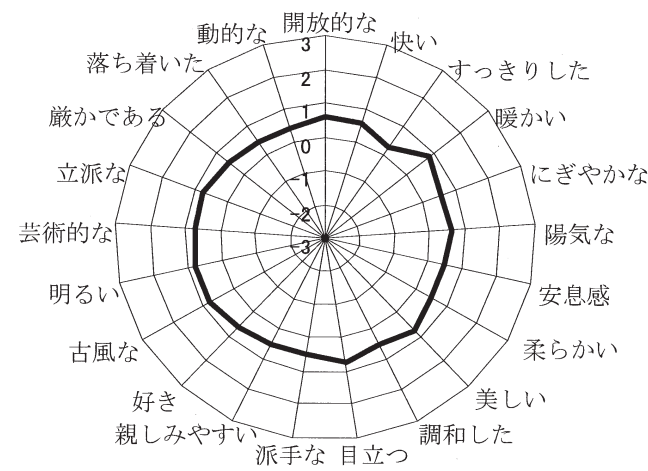

$[c]$

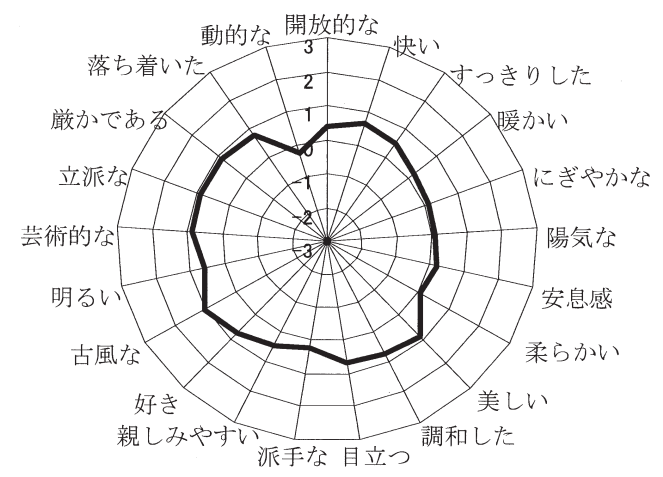

$[d]$

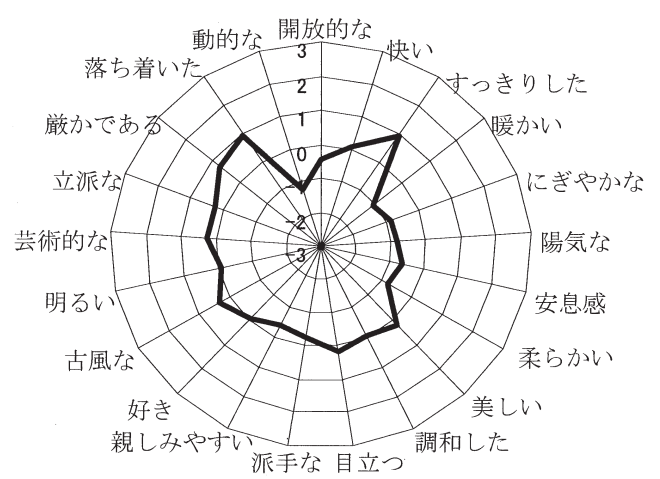

図 2 サンプルの平均評価値

Fig.2 Average evaluation for all samples.

[a] $2000 \mathrm{~K}$, [b] $3000 \mathrm{~K}$, [c] $5500 \mathrm{~K}$, [d] $10000 \mathrm{~K}$

和した, 美しい等の形容詞の評価値が大きい. $10000 \mathrm{~K}$ ([d]）の 結果より; 動的な, 暖かい等は, 色温度が高くなるにつれて評価 は落ちるが, 落ち着いた, すっきりした等は評価が高くなり, 色 温度によって変化する評価項目であることが示された。 
表 2 因子負荷量·寄与率·共通性

Table 2 Result of factor analysis.

\begin{tabular}{|c|c|c|c|c|}
\hline 変数名 & 因子No. 1（活動性） & 因子№. 2（評価性） & 因子NNo. 3（古風性） & 共通性（初期值） \\
\hline 暖かい & 0.928370205 & 0.332456971 & 0.059536805 & 0.9606 \\
\hline 動的な & 0.900708921 & 0.340941903 & -0.062784004 & 0.9315 \\
\hline にぎやかな & 0.875443959 & 0.426339967 & -0.147130911 & 0.9956 \\
\hline 柔らかい & 0.875256446 & 0.417724264 & 0.034939362 & 0.9606 \\
\hline 陽気な & 0.866826392 & 0.433434433 & -0.050990355 & 0.9556 \\
\hline 安息感 & 0.74548709 & 0.547778009 & 0.054949753 & 0.9276 \\
\hline 開放的な & 0.73956373 & 0.601419662 & -0.159849742 & 0.9372 \\
\hline 明るい & 0.68221225 & 0.562301473 & -0.351746526 & 0. 9004 \\
\hline 派手な & 0. 678014304 & 0.454628015 & -0.458963546 & 0.8995 \\
\hline 親しみやすい & 0.646345527 & 0.646436176 & 0.090729232 & 0.8988 \\
\hline すっきりした & -0.814645507 & 0.258376213 & -0.250189042 & 0.7459 \\
\hline 落ち着いた & -0.857128307 & 0.208070596 & 0.164338748 & 0.7459 \\
\hline 美しい & 0.227480771 & 0.914876772 & -0.133694711 & 0.8971 \\
\hline 芸術的な & 0.238097378 & 0.875010664 & 0.22136416 & 0.8965 \\
\hline 調和した & 0.103260302 & 0.873692753 & 0.127868551 & 0.8760 \\
\hline 好き & 0.239683328 & 0.87267603 & -0.051518431 & 0.8971 \\
\hline 快い & 0.268095968 & 0.849064522 & -0.088172683 & 0.8856 \\
\hline 立派な & 0.248646581 & 0.832623837 & 0.072883499 & 0.8965 \\
\hline 厳かである & -0.542498621 & 0.577593818 & 0.074805598 & 0.6983 \\
\hline 古風な & 0.015914484 & 0.531430647 & 0.63074946 & 0.6277 \\
\hline 目立つ & 0.538923819 & 0.538041245 & -0.303821999 & 0.8748 \\
\hline 寄与率 & $41.41 \%$ & $37.77 \%$ & $5.18 \%$ & \\
\hline 累積寄与率 & $41.41 \%$ & 79. $18 \%$ & $84.36 \%$ & \\
\hline
\end{tabular}

\section{4. 因子分析結果及び考察}

上述の評価実験で得られた各評価項目の平均評価值に因子分析 を適用し，全サンプルの評価に関係する因子の抽出を行った．第 3 因子まで抽出したところで累積寄与率が $84.36 \%$ となったため 因子の抽出をを打ち切った。これは評価項目のほとんどを第 3 因 子までで説明できると考えられるからである.

表 2 に各評価項目の因子負荷量・寄与率と共通性を示寸。因子 負荷量は因子が各評価項目に及ぼす影響力を示し, 因子の解棌は 因子負荷量によって行われる。 また, 共通性は各評価項目が今回 抽出された 3 つの因子でどれぐらい説明されるかを表し, その数 值が 1 から離れているほど実験誤差やその実験のみに固有な性質 が大きい4．

表 2 より，第 1 因子には，「暖かい」，「動的な」，「にぎやか」， 「柔らかい」,「陽気な」,「安息感」,「開放的な」,「明るい」,「派 手な」、「親しみや寸い」等が含まれることから, 第 1 因子を『活 動性』と名付けた，第 2 因子には, 「美しい」,「芸術的な」, 「調和 した」,「好き」、「快い」,「立派な」等が含まれるという特徴より, 第 2 因子を『評価性』と名付けた。第 3 因子には, 「古風な」とい った形容詞の因子負荷量が目立つため, 以上同様に，第 3 因子を 『古風性』と呼ぶことにした ${ }^{5}$.

図 3 は各サンプルの因子得点をそれぞれ，[a] 第 1 因子（x 軸） と第 2 因子（y 軸），［b] 第 2 因子（y 軸）と第 3 因子（ $\mathrm{z}$ 軸）を 座標軸にとった平面座標に示したものである. 図中の印はそれぞ れ四段階の照明光源を用いた各サンプルの結果に対応している.

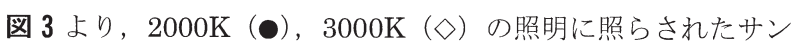
プルは第 1 因子軸のプラス側に, $5500 \mathrm{~K}$ (ロ) の照明を用いたサ ンプルは第 2 因子軸のプラス側に位置する傾向が示されている. この事から，2000K と $3000 \mathrm{~K}$ の照明では，伝統的景観に活動的 な印象を与え, $5500 \mathrm{~K}$ の照明では, 評価の高い印象を与えること

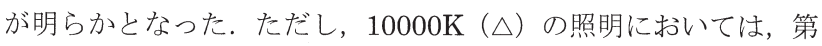

[a]

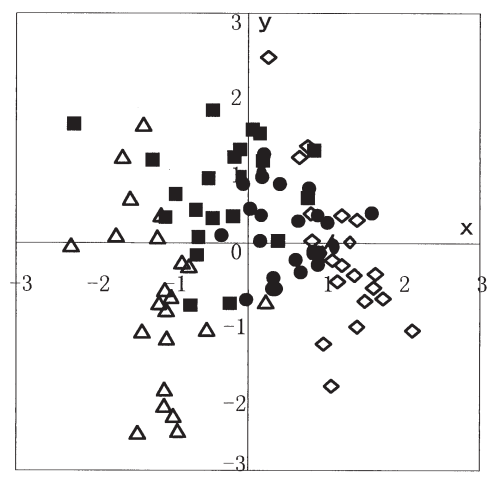

[b]

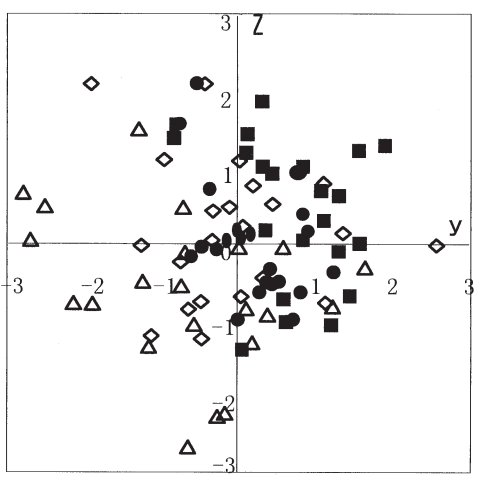

図3 サンプルの因子得点分布

Fig.3 Factor analysis points evaluation for all sample.

[a]Activity points to value points.

[b]Value points to traditional points.

$\mathrm{X}$-axis is factor $1, \mathrm{Y}$-axis is factor $2, \mathrm{Z}$-axis is factor 3 $2000 \mathrm{~K}(\bullet), 3000 \mathrm{~K}(\diamond), 5500 \mathrm{~K}(\bullet), 10000 \mathrm{~K}(\triangle)$ 
1 因子, 第 3 因子軸のマイナス側に多く位置することも示された. 伝統的景観に，青味を含んだ照明は適していないと言える.

\section{5. まとめ}

以上より, 伝統的建築物に最適な色温度を検討した。 その結果 として, まず, 全項目の視覚評価から, 4 段階照明光源の中では $10000 \mathrm{~K} よ り ， 2000 \mathrm{~K} ， 3000 \mathrm{~K} ， 5500 \mathrm{~K}$ の評価值が大きいことが 示された。 また, 因子分析によって, 今回使用した景観サンプル は,「活動性因子」,「評価性因子」,「古風性因子」の 3 因子構造を している事が分かった，さらに，これらを用い，各サンプルの因 子スコアを算出することによって, 色温度の低い照明 (2000K, 3000K）は伝統的な建築物に活動的な印象を与える. 5500K の照 明に照らされた伝統的建築物は高く評価されることが明らかとな った. したがって, 伝統的な建築物にふさわしい照明光源の色温 度は $2000 \mathrm{~K}, 3000 \mathrm{~K}, 5500 \mathrm{~K}$ 付近であると考えられる.

本研究では, 伝統的建築物に, 最適な夜間景観照明光源の色温 度を決定するという目的をある程度, 達成したと言える。しかし, 本研究には, 今後の課題として, 今回の研究結果を踏まえ, 伝統 的建築物の外壁色や被験者の年齢層等の条件を加えて, 更に, 分 析・解決していく必要がある.

\section{参 考 文 献}

(1) Osgood, C. E : Semantic Differential Technique in Compara tive Study of Cultures,Amer.Anthropologist,66,pp.171-200 (1964) .

(2) Osgood, C. E : Studies on the Generality of Affective Mean ing Systems, Amer. Psychol, 17, pp.10-28,(1964).

(3) 森典彦: ラフ集合と感性工学, 日本ファジイ学会誌， 13,66 , pp.52-59(2001).

（4）奥野忠一ほか：多変量解析法，日科技連出版社(1971).

（5）熊本忠彦, 太田公子: 印象に基づく検索ための印象語選定法 の提案，情報処理学会論文誌，44,7,pp.1808-1811(2001).

（受付日 2009 年 9 月 16 日/採録日 2010 年 5 月 7 日）

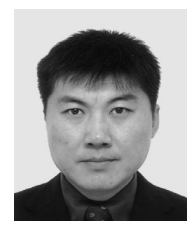

張 明（非会員）

富山大学大学院理工学教育部博士後期課程

数理・ヒューマンシステム科学専攻

干930-8555 富山県富山市五福 3190

2008 年 4 月富山大学大学院理工学教育部博士

後期課程数理・ヒューマンシステム科学専攻入学. 現在, 在学中. 非会員.

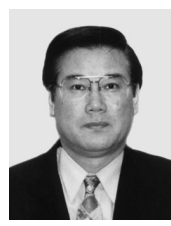

中嶋 芳雄 (専門会員)

富山大学大学院理工学研究部

干930-8555＼cjkstart富山県富山市五福 3190

昭和 55 年 3 月東京工業大学大学院総合理工学 研究科物理情報工学専攻博士課程修了, 平成 5 年 4 月富山大学工学部電子情報工学科助教授. 現在同大学大学 院教授. 工学博士. 照明学会, 応用物理学会, 日本光学会, 日 本人間工学会, 日本色彩学会, 日本視覚学会, 日本眼光学学会, 電気学会, 電気設備学会, 映像情報メディア学会会員.

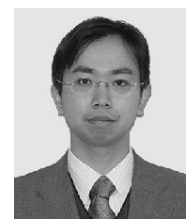

高松 衛（専門会員）

富山大学大学院理工学研究部

†930-8555 富山県富山市五福 3190

平成 12 年 3 月富山大学大学院博士後期課程修

了. 同年 4 月富山大学工学部知能情報工学科 勤務. 現在同大学大学院講師. 工学博士. 照明学会, 日本光学 会, 日本色彩学会, 日本眼光学学会, 電気学会, 電気設備学会, 映像情報メディア学会, 日本感性工学会, 日本人間工学会会員.

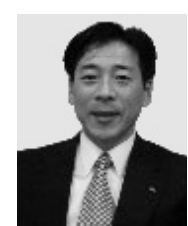

千代 和夫（専門会員）

パナソニック電工創研（株）

干571-8686 大阪府門真市大字門真 1048

昭和 50 年 3 月, 富山大学工学部卒業. 同年 4 月，松下電工（株）に入社，照明学会，電気 設備学会, 日本人間工学会会員.

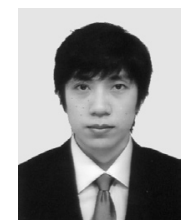

馬 林 (非会員)

富山大学大学院理工学教育部修士課程 知能情報工学専攻

干930-8555 富山県富山市五福 3190 2009 年 4 月富山大学大学院理工学教育部知能 情報工学専攻入学. 現在, 在学中. 非会員. 